\title{
AGRICULTURAL ABANDONMENT IN CHOSEN TERRAIN ATTRIBUTES CONTEXT - CASE STUDY FROM THE POLANA UNESCO BIOSPHERE RESERVE (CENTRAL SLOVAKIA)
}

\author{
MATEJ MASNÝ ${ }^{1}$, KAROL WEIS $^{1}$, MARTIN BOLTIŽIAR ${ }^{2}$
}

${ }^{1}$ Department of Geography and Geology, Faculty of Natural Sciences, Matej Bel University, Tajovského 40, 974 01, Banská Bystrica, Slovak Republic; e-mail: matej.masny@gmail.com, karol.weis@umb.sk

${ }^{2}$ Department of Geography and Regional Development, Faculty of Natural Sciences Constantine the Philosopher University in Nitra, Trieda A. Hlinku 1, 94974 Nitra, Slovak Republic; e-mail: mboltiziar@ukf.sk

\begin{abstract}
Masný M., Weis K., Boltižiar M.: Agricultural abandonment in chosen terrain attributes context case study from the Polana UNESCO Biosphere Reserve (Central Slovakia). Ekológia (Bratislava), Vol. 36, No. 4, p. 339-351, 2017.

Agricultural land in many post-socialist countries passed through a similar scenario of eminent changes in the past decades. One of the important milestones was the process of collectivisation (in 1950-1970), transformation to market-oriented economy (after 1989) and the following integration into the European Union. These changes were often attended by the process of agricultural abandonment. This paper presents an approach to the evaluation of agricultural abandonment by analysis of land use change in chosen terrain attributes (slope levels and altitude levels) context. It studies the area of a northern part of the Polana UNESCO (United Nations Educational, Scientific and Cultural Organization) Biosphere reserve that represents mountain agricultural landscape. All of the analyses were realised in GIS (geographic information systems), based on the orthophotos that represented the land use structure in 1949, 1986 and 2006. Dramatic decrease in real usage of agricultural areas attended by the process of secondary succession was observed especially in steep slopes and higher altitude levels. To quantify the changes, landscape metrics such as class area (CA), number of patches (NP) and mean patch size (MPS) were used. Changes in landscape classes had an influence on landscape diversity. It was expressed by decrease in Shannon's diversity index (SDI) and Shannon's evenness index (SEI).
\end{abstract}

Key words: agricultural abandonment, mountain agricultural landscape, landscape metrics.

\section{Introduction}

European agricultural land is constantly changing, following different development trajectories. On the one hand, they are urbanisation trends and agricultural intensification. On the other hand, some mountain areas have faced land abandonment (Van Vliet et al., 2015).

Agricultural abandonment was an opposite process of agricultural intensification (MacDonald et al., 2000). The negative effects of agricultural land abandonment may include the loss of particular biodiversity and increased spread of fires, particularly in the southern 
latitudes. Abandonment encourages the loss of landscape attractiveness and landscape heterogeneity, as well as its cultural heritage (Pazúr et al., 2014).

Agricultural abandonment is widespread in several regions of the world (Cramer et al., 2008), including North America (Parody et al., 2001), monsoonal Asia (Fukamachi et al., 2005; Tokuoka et al., 2011, Osawa et al., 2013), northern Europe (Robinson, Sutherland, 2002) and southern Europe (Ostermann, 1998). These processes have a distinctive character in post-socialist countries of central and eastern Europe (Baur et al., 2006; Müller, Munroe, 2008; Kuemmerle et al., 2008; Müller et al., 2009; Kuemmerle et al., 2011; Lieskovský et al., 2014, 2015). In many post-socialist countries, agricultural land abandonment began to dominate remarkably after 1989. Dismantling of the state-command system, introduction of free-market principles, withdrawal of governmental regulation and support and land reforms caused fundamental changes in all sectors of the economy, including agricultural land use (Lerman et al., 2004; Lioubimtseva, Henebry, 2008). This era was called transformation period. Agricultural cooperatives started to be transformed and the market started to be liberalised. This led to a decrease in agricultural production and often also to rural migration (Müller, Sikor, 2006; Müller et al., 2009). This is a typical scenario of agricultural abandonment in post-socialist countries. According to Prishchepov et al. (2012a), the highest rates of land abandonment since 1990 were observed in Latvia (42\% of all agricultural land in 1990 was abandoned by 2000), followed by Russia (31\%), Lithuania (28\%), Poland (14\%) and Belarus (13\%).

But, in many areas, we can observe the process of agricultural abandonment earlier. This has a relationship with the process of collectivisation. In Slovakia, this process occurred mainly in 1950-1970 and brought eminent changes to agricultural land use structure. Most of the traditional farming forms were transformed into large-scale fields (Lieskovský et al., 2014). Agricultural areas that were not interesting for collective farming (especially for difficult local terrain conditions, etc.) were abandoned.

This study analyses agricultural landscape of the northern part of the Polana UNESCO Biosphere reserve. The main aim is to create a multitemporal analysis of agricultural abandonment evolution in relation to the selected terrain attributes and an analysis of landscape diversity change.

\section{Study area}

Study area (Fig. 1) covers 7,850.19 ha in an altitudinal zone spanning from 399.5 to $1,272.5$ $\mathrm{m}$ a.s.l. It is an area of two municipalities - Lubietová and Strelníky. Study area is ranked as an archetype of a landscape with a focused texture of arrangement of land-use elements (Hreško et al., 2015). This study evaluates agricultural land and entire landscape of Lubietová and Strelníky for three time periods, namely, years 1949 (the state before collectivisation that took place there in 1958), 1986 (the socialist agriculture) and 2006 (the state of agricultural landscape after transformation). In agricultural land usage of study area, grasslands predominate (79.9\%). Arable land represents $14.9 \%$, and $5.2 \%$ is represented by traditional agricultural landscape (TAL). TAL areas are created by changing strips of arable field and grasslands. 


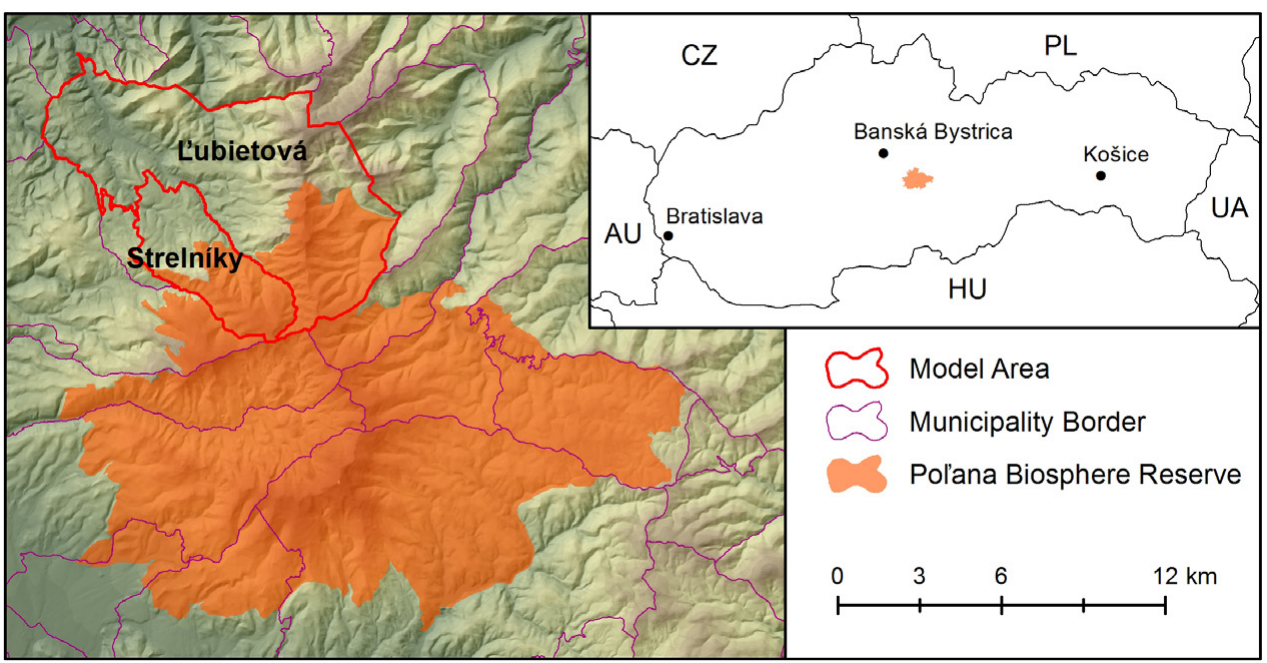

Fig. 1. Localisation of study area.

\section{Material and methods}

In the first phase, areas of agricultural land in official evidence (by data from National Agriculture and Food Centre - Soil Science and Conservation Research Institute) were analysed. These areas represented 2,889.70 ha (36.81\%) of the study area. First, these areas were divided by slope and second by altitude. To divide the study area into two approximately equal parts, values of slope and altitude, $12^{\circ}$ and $700 \mathrm{~m}$ a.s.l., respectively, were determined. According to slope, agricultural land was analysed below $12^{\circ}$ and above $12^{\circ}$. According to altitude, agricultural land was analysed below $700 \mathrm{~m}$ a. s. 1. and above $700 \mathrm{~m}$ a.s.l. Terrain attributes (slope levels and altitude levels) were calculated from the digital elevation model (DEM) with 10-m pixel resolution (DEM of Slovak Republic - Esprit, 2013). Analyses based on DEM are typical elements of local spatial scale studies (Vojtek, Vojteková, 2016; Druga, Faltan, 2014).

Usage of these areas (land use types) was categorised into three classes: agricultural usage (crops and permanent grasslands), non-forest woody vegetation (dispersed groups of trees and shrubs) and forest, for each time period. If woody vegetation met the conditions of forest by the Food and Agriculture Organization of the United Nations (FAO, 2010), these areas were classified as a forest. Similar analysis of abiotic variables in relation to land use was realised by Olah et al. (2006).

For describing land use structure in these parts, the most appropriate landscape metrics were chosen. Metrics were calculated on class level. Classes corresponded to the different land use types and each class consisted of numerous polygons - patches (Sidiropoulou et al., 2015). Principles of landscape metrics were defined in several relevant works (Forman, Godron, 1981; Gustafson, Parker, 1992; McGarigal, Marks, 1995; McGarigal et al., 2002; Cushman et al., 2008; Peng et al., 2010) and applied in studies of different regions (Faltan et al., 2011; Klaučo et al., 2013; Schindler et al., 2007; Baran-Zgłobicka, Zgłobicki, 2012; Súlovský et al., 2017, Kolejka, Ruda, 2017). For this study, three indexes (area metrics) have been chosen:

- $\quad$ Class area (CA) - is a measure of landscape composition; specifically how much of the landscape consists of one particular patch type (in hectares).

- $\quad$ Number of patches (NumP) - is a measure of landscape configuration that represents number of individual patches (polygons) of landscape elements. It refers to the spatial character of a class and indicates the extent of fragmentation.

- $\quad$ Mean patch size (MPS) - represents average patch size (in hectares) and it is a measure of landscape subdivision. Decrease in this value points on fragmentation of landscape mosaic. 
In the second phase, the entire landscape of the study area was analysed. Land use categories from the first phase were added by urbanisation and roads. The entire landscape was analysed according to two indexes (diversity metrics):

- Shannon's diversity index (SDI).

- Shannon's evenness index (SEI).

SDI refers to the number of different patch types, whilst SEI to the distribution of different patch types in an area. Diversity is a well-known property of ecosystems which is very useful in the characterisation of heterogeneity in time and space. Ecosystems with great diversity display great stability (McGarigal, Marks, 1995). Measuring of landscape diversity is useful not only for land use change evaluation but also for the prediction of potential impact on the structure and function of alternative land uses (Sidiropoulou et al., 2015).

For the landscape change analysis, orthophotos (raster) in high resolution (with $40 \mathrm{~cm}$ pixel size) registered in the coordinate system S-JTSK (Krovak's projection) were used. The data was provided by the Topographic Institute of Slovak Armed Forces. Using this data, categories of land use were classified on a large scale (1:3,000). All analyses were realised by using ArcMap 10.2 software (ESRI) with Patch Analyst 5.2 extension (Centre for Northern Forest Ecosystem Research).

\section{Results and discussion}

\section{a) Slope analyses}

On agricultural land in official evidence, significant changes were observed. Land use change had similar scenario in both slope categories (Fig. 2). In general, CA of agricultural usage decreased and that of forest increased, especially in period 1949-1986. This process was stronger in slope category $>12^{\circ}$.

CA of non-forest woody vegetation in slope category $<12^{\circ}$ was about the same level in all of the periods, but in slope category $>12^{\circ}$, more significant decrease was observed in period 1949-1986. Evaluation of all CA indexes pointed on the process of agricultural abandoning followed by secondary succession in higher slope areas especially in period 1949-1986.

Data concerning NumP pointed on the landscape fragmentation process (Fig. 2). NumP index had almost linearly increasing trend in both slope categories and in all periods. An exception is category of non-forest woody vegetation. NumP index of this category decreased in period 1949-1986 and increased in period 1986-2006. This was due to the transformation of many non-forest woody vegetation patches to forest especially in higher slope areas in period 1949-1986.

MPS index of non-forest woody vegetation was about the same level in both slope categories in all the periods (Fig. 2). MPS index of agricultural areas decreased in both slope categories but more significantly in slopes $>12^{\circ}$. MPS index of forest increased in period 1949-1986 and decreased in period 1986-2006. It pointed on the secondary succession process with creation of smaller forest patches in period 1986-2006. This process was more significant in slope category $>12^{\circ}$.

The effect of slope steepness on abandonment was confirmed by findings of Lieskovský et al. (2015). Agricultural land located on steep slopes was more likely to be abandoned. It was also confirmed by case studies from other parts of Slovakia (Bezák, Mitchley, 2014; Hreško et al., 2010).

The role of slope steepness is also influential in other post-socialist countries (Baumann et al., 2011; Kuemmerle et al., 2008; Müller et al., 2013; Opršal et al., 2013) or in Western 
Europe (MacDonald et al., 2000). However, according to Pazúr et al. (2014), slope steepness can also be used as an input factor for calculation of other predictors that made significant contribution to land abandonment (soil quality, accessibility and isolation variables, topographic wetness index).
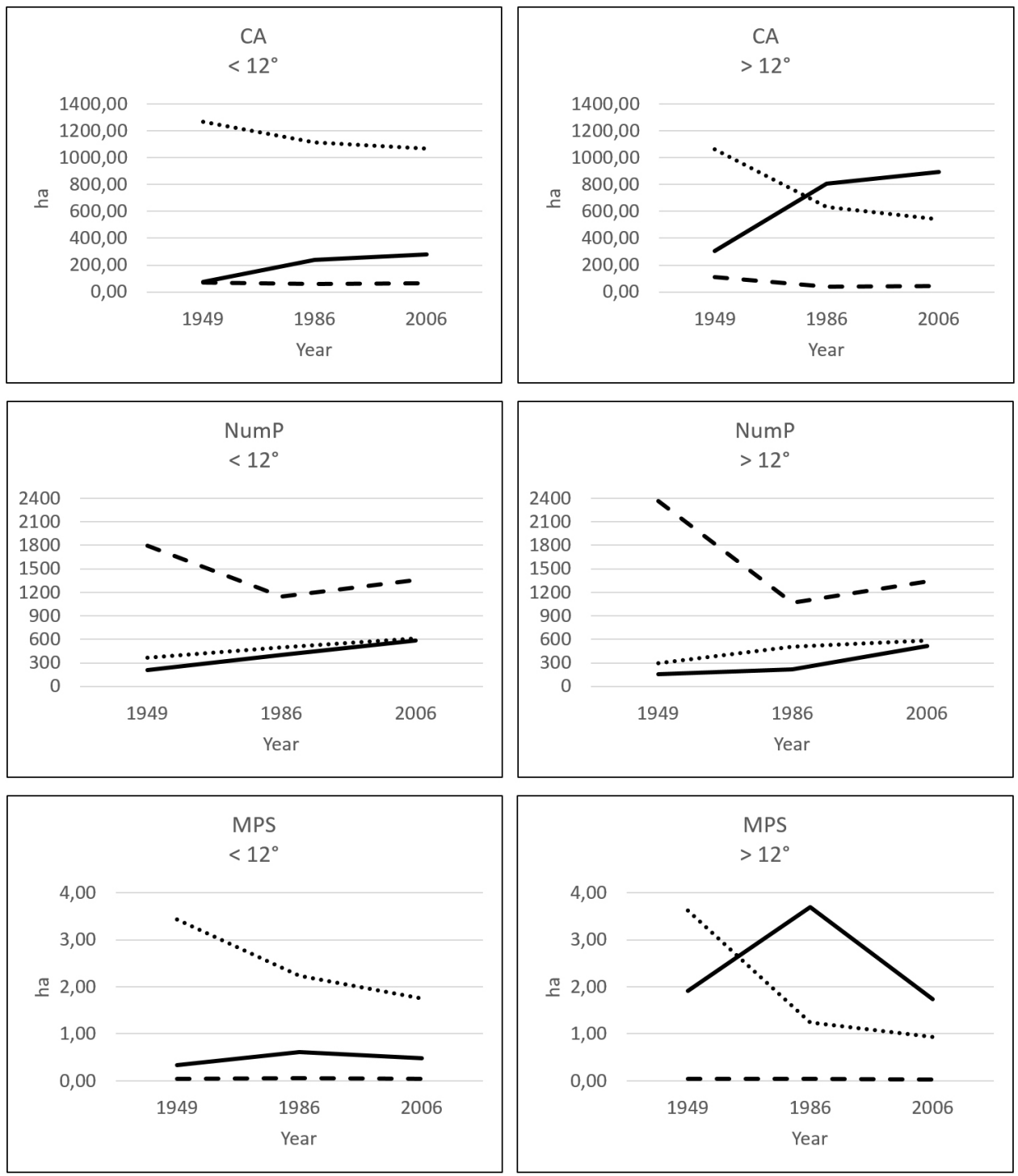

— Forest - Non-forest Woody Vegetation $\cdots .$. ... Agricultural Usage

Fig. 2. Evolution of class metrics on agricultural estates by slope levels. 


\section{b) Altitude analyses}

Process of agricultural abandoning followed by secondary succession was also confirmed in agricultural land evaluation by altitude levels (Fig. 3). Decreasing of agricultural usage area and
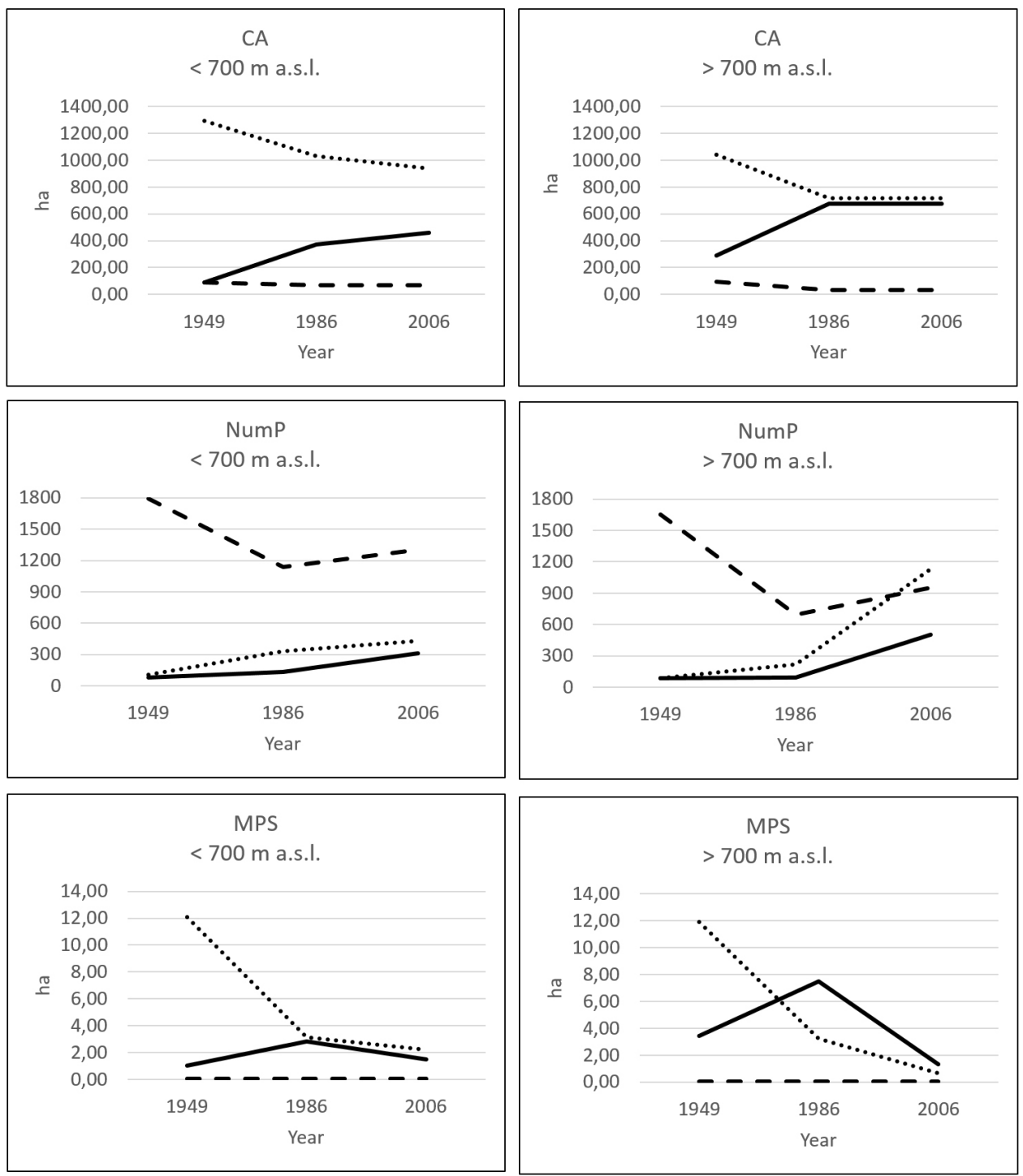

—Forest - - Non-forest Woody Vegetation ...... Agricultural Usage

Fig. 3. Evolution of class metrics on agricultural estates by altitude levels. 
increasing of forest area were characteristic for both altitude categories. In lower altitudes ( $<700 \mathrm{~m}$ a.s.l.), this process proceeded across all evaluated periods. But in higher altitudes (>700 $\mathrm{m}$ a.s.l.), CA indexes of agricultural usage and forest were about the same level in period 1986 and 2006. It pointed on stabilisation of the abandonment process in higher altitude areas.

Evolution of NumP index in the evaluation by altitude (Fig. 3) is very similar to that in the evaluation by slope (Fig. 2). Since 1986, an increasing number of all class patches, especially in class of agricultural usage, has been observed in category $>700 \mathrm{~m}$ a.s.l. It pointed on the process of landscape fragmentation with the formation of secondary succession patches.

The process of landscape fragmentation was also confirmed by MPS index. MPS of agricultural usage decreased dramatically in all the periods. In category $>700 \mathrm{~m}$ a.s.l., it declined to the level under 1 ha (Fig. 3). Evolution of forest MPS index by altitude levels (Fig. 3) was similar to that in evaluation by slope levels (Fig. 2).

Results of slopes and altitude analysis confirm the hypothesis that landscape remains closely associated to the terrain characteristics as a part of natural conditions of the territories (Bürgi et al., 2009; Kolejka, 1987). Altitude and slope were also identified as a main geographical factor affecting the abandonment in other post-socialist countries, for example, Ukraine (Baumann et al., 2011), the cross-border triangle of Slovakia, Poland and Ukraine (Kuemmerle et al., 2008), in selected regions of Romania and Albania (Müller et al., 2013). The overall increase in the use of heavy machinery in 1950s (collectivisation era) could be the reason for abandonment of steep slopes and areas in higher altitudes. These areas were not well accessible for heavy machinery (Hreško et al., 2010).

On the other hand, the influence of natural conditions on agricultural abandonment in collectivisation era could be suppressed by different agro-policies of each country. Lower agricultural land abandonment rates might exist where market mechanisms were complemented by stronger connections of the landowners to their former properties (Prishchepov

$\mathrm{T} \mathrm{a} \mathrm{b}$ l e 1. Representation of basic land use categories.

\begin{tabular}{|l|c|c|c|c|c|c|c|}
\hline \multirow{2}{*}{ Class } & & $\mathbf{1 9 4 9}$ & $\mathbf{1 9 8 6}$ & $\mathbf{2 0 0 6}$ & $\begin{array}{c}\text { Difference } \\
\mathbf{1 9 4 9 - 1 9 8 6}\end{array}$ & $\begin{array}{c}\text { Difference } \\
\mathbf{1 9 8 6 - 2 0 0 6}\end{array}$ & $\begin{array}{c}\text { Difference } \\
\mathbf{1 9 4 9 - 2 0 0 6}\end{array}$ \\
\hline \multirow{2}{*}{ Forest } & ha & $4,924.46$ & $5,705.98$ & $5,832.83$ & +781.52 & +126.85 & +908.37 \\
\cline { 2 - 8 } & $\%$ & 62.73 & 72.69 & 74.30 & +9.96 & +1.62 & +11.57 \\
\hline \multirow{2}{*}{$\begin{array}{l}\text { Non-forest Woody } \\
\text { Vegetation }\end{array}$} & ha & 190.93 & 100.94 & 108.01 & -89.99 & +7.07 & -82.92 \\
\cline { 2 - 8 } & $\%$ & 2.43 & 1.29 & 1.38 & -1.15 & +0.09 & -1.06 \\
\hline \multirow{2}{*}{ Agricultural Usage } & ha & $2,503.57$ & $1,747.31$ & $1,608.28$ & -756.26 & -139.03 & -895.28 \\
\cline { 2 - 8 } & $\%$ & 31.89 & 22.26 & 20.49 & -9.63 & -1.77 & -11.40 \\
\hline \multirow{2}{*}{$\begin{array}{l}\text { Urbanisation and } \\
\text { Roads }\end{array}$} & ha & 224.76 & 288.94 & 294.04 & +64.18 & +5.11 & +69.28 \\
\hline \multirow{2}{*}{ Others } & ha & 2.86 & 3.68 & 3.75 & +0.82 & +0.07 & +0.88 \\
\hline \multirow{2}{*}{ Total } & $\%$ & 0.08 & 0.09 & 0.09 & +0.01 & 0.00 & +0.55 \\
\hline
\end{tabular}




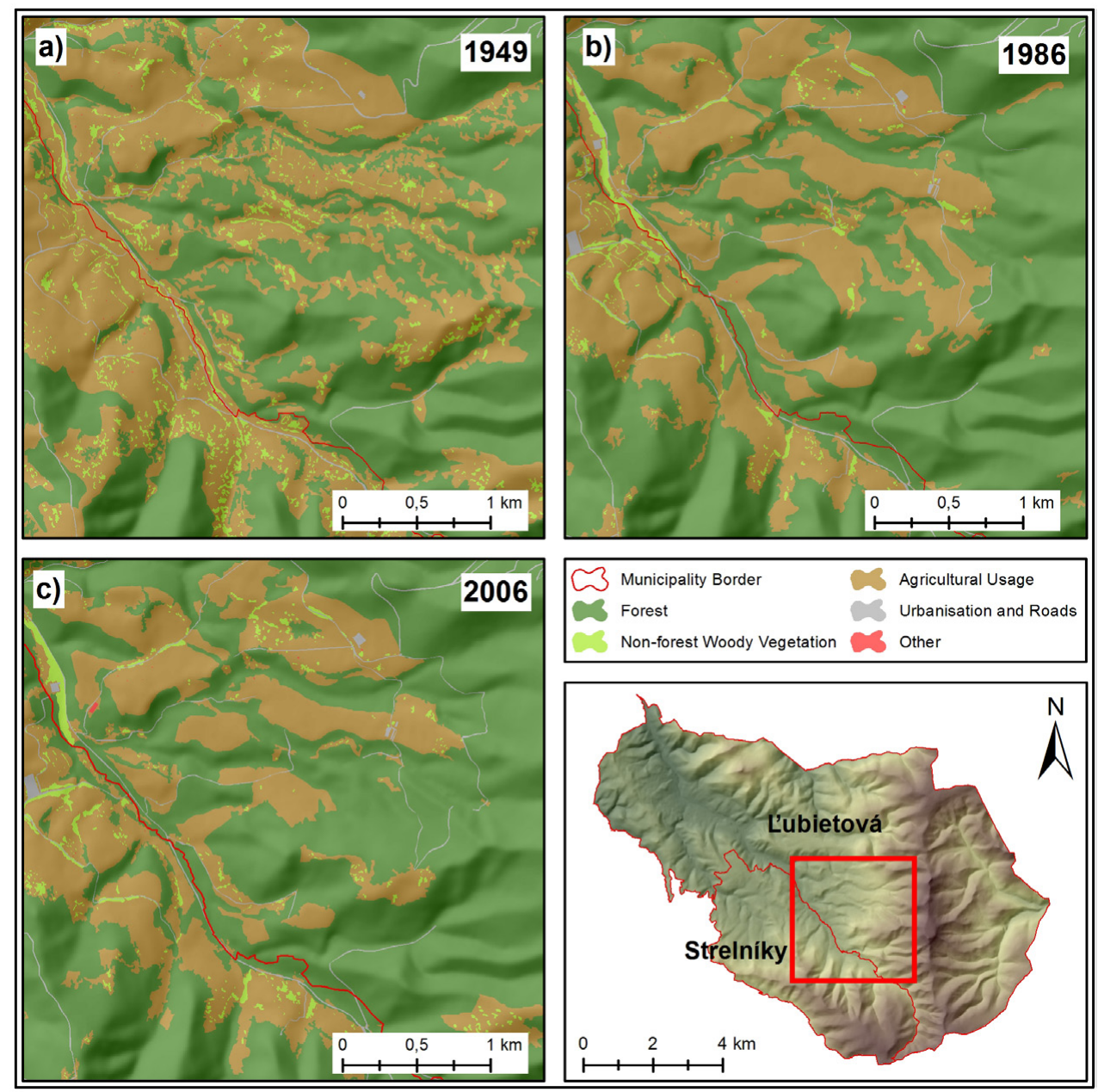

Fig. 4. Illustration of a change in land use in the study area.

et al., 2012a; Macey et al., 2004; Lerman et al., 2004; Stuikys, Ladyga, 1995; Turnock, 1998). In Poland, the majority of the agricultural land was in private property during socialism and no change in ownership was necessary. In this country with similar agro-ecological conditions, minor agricultural land abandonment can be observed (Turnock, 1998; Prishchepov et al., 2012a). Considerable influence of different agro-reform policies (after 1990) was confirmed by cross-border studies from areas where the natural conditions are similar (Hostert et al., 2011; Kuemmerle et al., 2008), for example, cross-border area of Belarus and Lithuania (abandonment rate 28 and 14\%, respectively, Prishchepov et al., 2012b). 


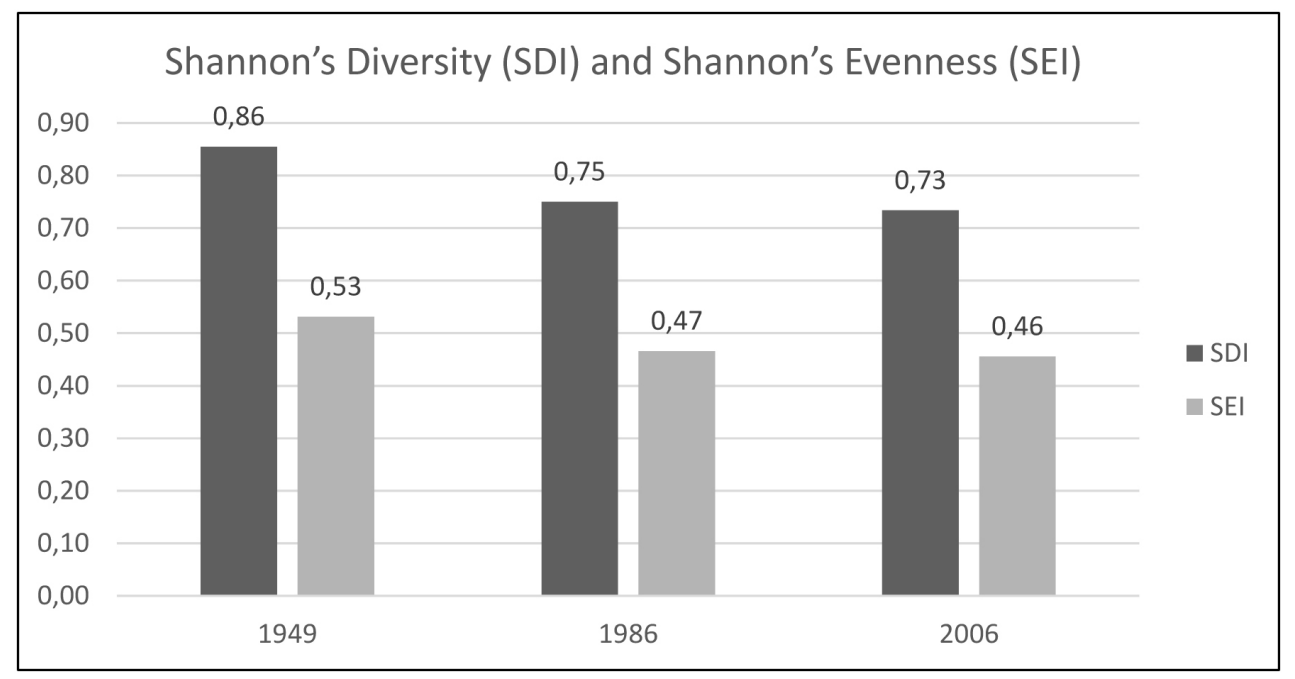

Fig. 5. Shannon's diversity and Shannon's evenness indexes in each period.

\section{c) Landscape heterogeneity}

Land use change analysis on the entire landscape level confirmed previous findings concerning the process of agricultural abandonment and secondary succession. Changes in area of each landscape class are depicted in the Table 1.

In the study area, an increasing trend of especially forest category was observed (Fig. 4). A part of forest category that increased is almost of the same extent as a part of agricultural usage category that decreased (Table 1). The rapid increase in forest and non-forest woody vegetation category is typical for Slovakia and other post-socialist countries (Druga, Faltan, 2014; Griffiths et al., 2013; Shandra et al., 2013; Munteanu et al., 2014). Expansion of forest and shrub lands at the expense of semi-natural grasslands is a result of traditional agricultural practice reduction (Riecken et al., 2002; Olsson et al., 2000). Forest canopies that originate on abandoned agricultural land are primarily determined by natural environmental conditions. Nevertheless, the type of previous land use also modifies the species compositions of these forests and needs to be considered as an important determinant of their composition (Kopecký, Vojta, 2009).

The impact of main changes (agricultural abandonment and secondary succession) on the landscape diversity was expressed by SDI and SEI. These indexes pointed on a decrease in diversity and evenness level, especially in period 1949-1986 (Fig. 5), that means in period of the most significant increase in secondary succession. A landscape structure of the study area was more stable and diversified before the era of collectivisation. Abandoning of traditional agricultural practice with changes in vegetation composition because of secondary succession brought marked changes in landscape diversity. 
Reduction of landscape diversity is in direct relation to the reduction of biodiversity. Agricultural activities (especially grazing) exert a strong effect on vegetation dynamics (Sidiropoulou et al., 2015) and on species and community diversity (Sternberg et al., 2000; Baur et al., 2006). Traditional agricultural activities also have an impact on the spatial heterogeneity of vegetation, affecting ecosystem processes and landscape diversity (Adler et al., 2001). Grazing and other pastoral activities create openings and corridors in forests and rangelands resulting in the emergence of mosaic - Fig. 4 (a) - such as landscapes and vegetation changes both along the routes and on highland rangelands (Sidiropoulou et al., 2015).

\section{Conclusion}

The results of realised analyses pointed on the processes of agricultural land abandonment and secondary succession. The reason of these processes could be find in socio-economic changes (collectivisation, transformation period after 1989). Since 1949, the area of agricultural land with real agricultural usage has decreased to about $11.40 \%$ in the study area. The influence of the chosen terrain attributes was confirmed. These processes were more significant in the areas with higher slope levels $\left(>12^{\circ}\right)$ and higher altitudes $(>700 \mathrm{~m}$ a.s.l.). However, the major part of the land use change took place in the period 1949-1986. It means during socialistic agricultural era, not only after 1990. By the actual terrain exploration, abandoned agricultural areas have not been revitalised since 2006. The abandonment process in other areas of Lubietová and Strelníky is currently not in progress, which can be caused by the application of European Union`s Common agricultural policy. The change in land use observed in the study periods does not mean only the loss of agricultural land but also a decrease in landscape diversity. It is a very negative phenomenon, especially in a spatial context of the Polana UNESCO Biosphere Reserve that should be an excellent region of harmony between human utilising and biodiversity conservation.

\section{Acknowledgements}

The paper was supported by the project of grant agency VEGA 1/093417 'Land-use changes of Slovak cultural landscape over the past 250 years and prediction of its further development'.

\section{References}

Adler, P.B., Raff, D.A. \& Lauenroth W.K. (2001). The effect of grazing on the spatial heterogeneity of vegetation. Oecologia, 128, 465-479. DOI: 10.1007/s004420100737.

Baran-Zgłobicka, B. \& Zgłobicki W. (2012). Mosaic landscapes of SE Poland: should we preserve them? Agrofor. Syst., 85, 351-365. DOI: 10.1007/s10457-011-9436-x.

Baumann, M., Kuemmerle, T., Elbakidze, M., Ozdogan, M., Radeloff, V.C., Keuler, N.S., Prishchepov, A.V., Kruhlov, I. \& Hostert P. (2011). Patterns and drivers of postsocialist farmland abandonment in Western Ukraine. Land Use Policy, 28, 552-562. DOI: 10.1016/j.landusepol.2010.11.003.

Baur, B., Cremene, C., Groza, G., Rakosy, L., Schileyko, A.A., Baur, A., Stoll, P. \& Erhardt A. (2006). Effects of abandonment of subalpine hay meadows on plant and invertebrate diversity in Transylvania, Romania. Biol. Conserv., 132, 261-273. DOI: 10.1016/j.biocon.2006.04.018.

Bezák, P. \& Mitchley J. (2014). Drivers of change in mountain farming in Slovakia: from socialist collectivisation to the common agricultural policy. Regional Environmental Change, 14(4), 1343-1356. DOI: 10.1007/s10113013-0580-x. 
Bürgi, M., Straub, A., Gimmi, U. \& Salzmann D. (2009). The recent landscape history of Limpach valley, Switzerland: considering three empirical hypotheses on driving forces of landscape change. Landsc. Ecol., 25, 287-297. DOI: 10.1007/s10980-009-9412-2.

Cramer, V.A., Hobbs, R.J. \& Standish R.J. (2008). What's new about old fields? Land abandonment and ecosystem assembly. Trends Ecol. Evol., 23, 104-112. DOI: 10.1016/j.tree.2007.10.005.

Cushman, S.A., McGarigal, K. \& Neel M.C. (2008). Parsimony in landscape metrics: strength, universality, and consistency. Ecological Indicators, 8, 691-703. DOI: 10.1016/j.ecolind.2007.12.002.

Druga, M. \& Faltan V. (2014). Influence of environmental drivers on the land cover structure and its long-term changes - case study of Malachov and Podkonice villages in Slovakia. Moravian Geographical Reports, 22(3), 29-41. DOI: 10.2478/mgr-2014-0016.

Faltan, V., Bánovský, M. \& Blažek M. (2011). Evaluation of land cover changes after extraordinary windstorm by using the land cover metrics: a case study on the High Tatras foothill. Geografie, 116(2), 156-171.

FAO (2010). Food and Agriculture Organization of the United Nations, Forest Resources Assessment Programme, Working paper 144/E - Terms and Definitions, 2010. Rome: Forestry Department of FAO.

Forman, R.T.T. \& Godron M. (1981). Patches and structural components for a landscape ecology. Bioscience, 31, 733-740. DOI: 10.2307/1308780.

Fukamachi, K., Oku, H. \& Miyake A. (2005) The relationships between the structure of paddy levees and the plant species diversity in cultural landscapes on the west side of Lake Biwa, Shiga, Japan. Landscape Ecology Engineering, 1, 191-199. DOI: 10.1007/s11355-005-0019-8.

Griffiths, P., Müller, D., Kuemmerle, T. \& Hostert P. (2013). Agricultural land change in the Carpathian ecoregion after the breakdown of socialism and expansion of the European Union, Environmental Research Letters, 8(4), 045024. DOI: 10.1088/1748-9326/8/4/045024.

Gustafson, E.J. \& Parker G. (1992). Relationships between land cover proportion and indices of landscape spatial pattern. Landsc. Ecol., 7, 101-110. DOI: 10.1007/BF02418941.

Hostert, P., Kuemmerle, T., Prishchepov, A.V., Sieber, A., Lambin, E.F. \& Radeloff V.C. (2011). Rapid land-use change after socio-economic disturbances: the collapse of the Soviet Union versus Chernobyl. Environmental Research Letters, 6(4), 045201. DOI: 10.1088/1748-9326/6/4/045201.

Hreško, J., Kanasová, D. \& Petrovič F. (2010). Landscape archetypes as the elements of slovak historical landscape structure, Ekológia (Bratislava), 29, 158-173. DOI: 10.4149/ekol_2010_02_158.

Hreško, J., Petrovič, F. \& Mišovičová R. (2015). Mountain landscape archetypes of the Western Carpathians (Slovakia). Biodivers. Conserv., 24(13), 3269-3283. DOI: 10.1007/s10531-015-0969-6.

Klaučo, M., Gregorová, B., Stankov, M., Marković, V. \& Lemenkova P. (2013). Determination of ecological significance based on geostatistical assessment: a case study from the Slovak Natura 2000 protected area. Central European Journal of Geosciences, 5(1), 28-42. DOI: 10.2478/s13533-012-0120-0.

Kolejka, J. (1987). Landscape-historical synthesis, materials, methods and results. Ekológia (ČSSR), 6(1), 51-62.

Kolejka, J. \& Ruda A. (2017). The choice of an area zonation method based on the territorial share of industrial society heritage: The post-industrial cultural landscape Kamenicko as a case study (in Czech). Geografie - Sborník České Geografické Společnosti, 122(3), 335-358.

Kopecký, M. \& Vojta J. (2009). Land use legacies in post-agricultural forests in the Doupovské Mountains, Czech Republic. Appl. Veg. Sci., 12, 251-260. DOI: 10.1111/j.1654-109X.2009.01023.x.

Kuemmerle, T., Hostert, P., Radeloff, V.C., Van der Linden, S., Perzanowski, K. \& Kruhlov I. (2008). Cross-border comparison of postsocialist farmland abandonment in the Carpathians. Ecosystems, 11, 614-628. DOI: 10.1007/s10021-008-9146-Z.

Kuemmerle, T., Olofsson, P., Chaskovskyy, O., Baumann, M., Ostapowicz, K., Woodcock, C.E., Houghton, R.A., Hostert, P., Keeton, W.S. \& Radeloff V.C. (2011). Post-Soviet farmland abandonment, forest recovery, and carbon sequestration in western Ukraine. Global Change Biology, 17, 1335-1349. DOI: 10.1111/j.13652486.2010.02333.x.

Lerman, Z., Csaki, C. \& Feder G. (2004). Agriculture in transition: Land policies and evolving farm structures in PostSoviet countries. Lanham, MD: Lexington Books.

Lieskovský, J., Kenderessy, P., Špulerová, J., Lieskovský, T., Koleda, P., Kienast, F. \& Gimmi U. (2014). Factors affecting the persistence of traditional agricultural landscapes in Slovakia during the collectivization of agriculture. Landsc. Ecol., 29, 867-877. DOI: 10.1007/s10980-014-0023-1.

Lieskovský, J., Bezák, P., Špulerová, J., Lieskovský, T., Koleda, P., Dobrovodská, M., Bürgi, M. \& Gimmi U. (2015). The abandonment of traditional agricultural landscape in Slovakia - Analysis of extent and driving forces. Journal of 
Rural Studies, 37, 75-84. DOI: 10.1016/j.jrurstud.2014.12.007.

Lioubimtseva, E. \& Henebry G.M. (2008). Climate and environmental change in arid Central Asia: impacts, vulnerability, and adaptations. J. Arid Environ., 73, 963-977. DOI: 10.1016/j.jaridenv.2009.04.022.

MacDonald, D., Crabtree, J.R., Wiesinger, G., Dax, T., Stamou, N., Fleury, P. Gutierrez Lazpita, J. \& Gibon A. (2000). Agricultural abandonment in mountain areas of Europe: Environmental consequences and policy response. J. Environ. Manag., 59, 47-69. DOI: 10.1006/jema.1999.0335.

Macey, D.J., Pyle, W. \& Wegren S.K. (Eds.) (2004). Building Market Institutions in Post- Communist Agriculture: Land, Credit, and Assistance. Lanham (MD): Lexington Books.

McGarigal, K. \& Marks B. (1995). FRAGSTATS spatial pattern analysis program for quantifying landscape structure. General Technical Report. United States Deparment of Agriculture, Forest Service, Pacific. [online]. Portland: Northwest Research Station. Available from Internet: http://andrewsforest.oregonstate.edu/pubs/pdf/pub1538. pdf [Cit. 27 February 2016]

McGarigal, K., Cushman, S.A., Neel, M.C. \& Ene E. (2002). FRAGSTATS: Spatial pattern analysis program for categorical maps. Computer software program produced by the authors at the University of Massachusetts, Massachusetts.

Müller, D. \& Sikor T. (2006). Effects of postsocialist reforms on land cover and land use in South-eastern Albania. Applied Geography, 26, 175-191. DOI: 10.1016/j.apgeog.2006.09.002.

Müller, D. \& Munroe D.K. (2008). Changing rural landscapes in Albania: Cropland abandonment and forest clearing in the postsocialist transition. Annals of the Association of American Geographers, 98, 855-876. DOI: $10.1080 / 00045600802262323$.

Müller, D., Kuemmerle, T., Rusu, M. \& Griffiths P. (2009). Lost in transition: determinants of post-socialist cropland abandonment in Romania. Journal of Land Use Science, 4, 109-129. DOI: 10.1080/17474230802645881.

Müller, D., Leitao, P.J. \& Sikor T. (2013). Comparing the determinants of cropland abandonment in Albania and Romania using boosted regression trees. Agric. Syst., 117, 66-77. DOI: 10.1016/j.agsy.2012.12.010.

Munteanu, C., Kuemmerle, T., Boltižiar, M., Butsic, V., Gimmi, U., Halada, L., Kaim, D., Kiraly, G., Konkoly-Gyur, E., Kozak, J., Lieskovský, J., Mojses, M., Müller, D., Ostafin, K., Ostapowicz, K., Shandra, O., Stych, P., Walker, S. \& Radeloff V.C. (2014). Forest and agricultural land change in the Carpathian region - A meta-analysis of longterm patterns and drivers of change. Land Use Policy, 38, 685-697. DOI: 10.1016/j.landusepol.2014.01.012.

Olah, B., Boltižiar, M. \& Petrovič F. (2006). Land use changes' relation to georelief and distance in the East Carpathians Biosphere Reserve. Ekológia (Bratislava), 25(1), 68-81.

Olsson, E.G., Austrheim, G. \& Grenne S. (2000). Landscape change patterns in mountains, land use and environmental diversity, mid-norway 1960-1993. Landsc. Ecol., 15, 155- 170. DOI: 10.1023/A:1008173628016.

Opršal, Z., Šarapatka, B. \& Kladivo P. (2013). Land-use changes and their relationship to selected landscape parameters in three cadastral areas in the Moravia Region, Czech Republic, Moravian Geographical Reports, 21(1), 41-50. DOI: $10.2478 / \mathrm{mgr}-2013-0004$.

Osawa, T., Kazunori, K. \& Hiromune M. (2013). Areas of increasing agricultural abandonment overlap the distribution of previously common, currently threatened plant species. PLoS One, 8(11), 9. DOI: 10.1371/journal. pone.0079978.

Ostermann, O.P. (1998). The need for management of nature conservation sites designated under Natura 2000. J. Appl. Ecol., 35, 968-973. DOI: 10.1111/j.1365-2664.1998.tb00016.x.

Parody, J.M., Cuthbert, F.J. \& Decker E.H. (2001). The effect of 50 years of landscape change on species richness and community composition. Glob. Ecol. Biogeogr., 10, 305-313. DOI: 10.1046/j.1466-822X.2001.00233.x.

Pazúr, R., Lieskovský, J., Feranec, J. \& Otahel' J. (2014). Spatial determinants of abandonment of large-scale arable lands and managed grasslands in Slovakia during the periods of post-socialist transition and European Union accession, Applied Geography, 54, 118-128. DOI: 10.1016/j.apgeog.2014.07.014.

Peng, J., Wang, Y., Zhang Y., Wua, J., Li, W. \& Li Y. (2010). Evaluating the effectiveness of landscape metrics in quantifying spatial patterns. Ecological Indicators, 10(2), 217-223. DOI: 10.1016/j.ecolind.2009.04.017.

Prishchepov, A., Radeloff, V.C., Baumann, M., Kuemmerle, T. \& Müller D. (2012a). Effects of institutional changes on land use: agricultural land abandonment during the transition from state-command to market-driven economies in post-Soviet Eastern Europe. Environmental Research Letters, 7(2), 024021. DOI: 10.1088/17489326/7/2/024021.

Prishchepov, A., Radeloff, V., Dubinin, M. \& Alcantara C. (2012b). The effect of Landsat ETM/ETM+ image acquisition dates on the detection of agricultural land abandonment in Eastern Europe. Remote Sens. Environ., 126, 195-209. DOI: 10.1016/j.rse.2012.08.017. 
Riecken, U., Finck, P. \& Schröder E. (2002). Significance of pasture landscapes for nature conservation and extensive agriculture. In B. Redecker, W. Härdtle, P. Finck, U. Riecken \& E. Schröder (Eds.), Pasture landscapes and nature conservation (pp. 423-435). Heidelberg: Springer.

Robinson, R.A. \& Sutherland W.J. (2002). Post-war changes in arable farming and biodiversity in Great Britain. J. Appl. Ecol., 39, 157-176. DOI: 10.1046/j.1365-2664.2002.00695.x.

Schindler, S., Poirazidis, K. \& Wrbka T. (2007). Towards a core set of landscape metrics for biodiversity assessments: a case study from Dadia National Park, Greece. Ecological Indicators, 8(5), 502-514. DOI: 10.1016/j. ecolind.2007.06.001.

Shandra, O., Weisberg, P. \& Martazinova V. (2013). Influences of climate and land use history on forest and timberline dynamics in the Carpathian mountains during the twentieth Century. In J. Kozak, K. Ostapowicz, A. Bytnerowicz \& B. Wyzga (Eds.), The Carpathians: Integrating nature and society towards sustainability (pp. 209-223). Berlin, Heidelberg: Springer.

Sidiropoulou, A., Karatassiou, M., Galidaki, G. \& Sklavou P. (2015). Landscape pattern changes in response to transhumance abandonment on mountain Vermio (North Greece). Sustainability, 7(11), 15652-15673. DOI: $10.3390 /$ su71115652.

Sternberg, M., Gutman, M., Perevolotsky, A., Ungar, E.D. \& Kigel J. (2000). Vegetation response to grazing management in a mediterranean herbaceous community: A functional group approach. J. Appl. Ecol., 37, $224-237$. DOI: 10.1046/j.1365-2664.2000.00491.x.

Stuikys, V. \& Ladyga A. (1995). Agriculture of Lithuania. Vilnius: Valystybinis Leidybos Centras.

Súlovský, M., Faltan, V., Skokanová, H., Havlíček, M. \& Petrovič F. (2017). Spatial analysis of long-term land-use development in regard to physiotopes: case studies from the Carpathians. Physical Geography, 38(5), 470-488. DOI: $10.1080 / 02723646.2017 .1318652$.

Tokuoka, Y., Ohigashi, K. \& Nakagoshi N. (2011). Limitations on treeseedling establishment across ecotones between abandoned fields and adjacent broad-leaved forests in eastern Japan. Plant Ecol., 212, 923-944. DOI: 10.1007/s11258-010-9868-9.

Turnock, T. (Ed.) (1998). Privatization in Rural Eastern Europe: The process of restitution and restructuring. Northampton (MA): Edward Elgar Publishing.

Van Vliet, J., De Groot, H.L.F., Rietveld, P. \& Verburg P.H. (2015). Manifestations and underlying drivers of agricultural land use change in Europe. Landsc. Urban Plann., 133, 24-36. DOI: 10.1016/j.landurbplan.2014.09.001.

Vojtek, M. \& Vojteková J. (2016). Flood hazard and flood risk assessment at the local spatial scale: a case study. Geomatics, Natural Hazards and Risk, 7(6), 1973-1992. DOI: 10.1080/19475705.2016.1166874. 